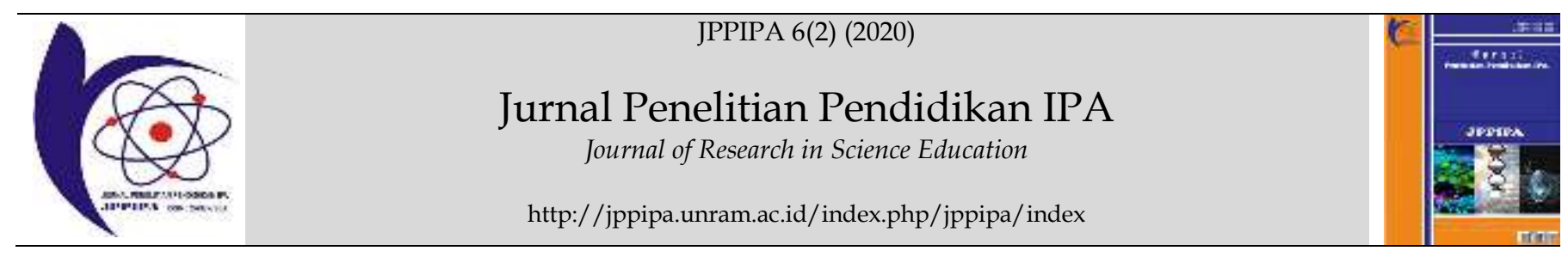

\title{
Development of Problem-Based Learning Student Worksheets to Facilitate Students' Problem Solving Skills
}

\author{
Sri Wahyuni ${ }^{*}$, Yuni Sri Rahayu², Sifak Indana ${ }^{3}$ \\ 1 Science Education Study Program Postgraduate, State University of Surabaya, Indonesia \\ ${ }^{2}$ Biology Education Study Program, State University of Surabaya, Indonesia \\ ${ }^{3}$ Biology Education Study Program, State University of Surabaya, Indonesia
}

\section{DOI: $10.29303 /$ jppipa.v6i2.427}

\section{Article Info}

Received : April 20th, 2020

Revised : June $5^{\text {th }}, 2020$

Accepted : June $12^{\text {th }}, 2020$

\begin{abstract}
The purpose of this study was to develop Problem-Based Learning student worksheets on bioremediation material to facilitate students authentic problem solving skills. The development used a procedural development model called ADDIE (Analysis, Design, Development, Implementation, Evaluation). The subjects in this study were Biology Students at Surabaya State University. Data collection used validation, observation, and test techniques. Student worksheets quality measurement obtained by a rating scale instrument in the form of a validation sheet. The developed teaching materials were in the form of Semester Learning Design, Unit Of Lectures, Student worksheets, and problem solving skills-based question for evaluation purposed. This developed teaching materials had been validated by experts, with scores of SLD 3.36, UOL scores 3.44, Student worksheets were 3.36 respectively. In addition, the average score of practicality and effectiveness in pre-test and post-test of the developed teaching materials were 4.00, 1.85, and 3.40 respectively. All the developed teaching materials were in very good qualifications. Based on data analyzed, it could be concluded that the developed student worksheets on bioremediation material was valid so that it can facilitate authentic problem solving skills in Biology Students at State University of Surabaya and is feasible to be used as a teaching learning materials.
\end{abstract}

Keywords: Student worksheets; Problem Based Learning; Problem Solving Skills; Bioremediation.

Citation: Wahyuni, S., Rahayu, Y.S., \& Indana, S. (2020). Development of Problem-Based Learning Student Worksheets to Facilitate Students' Problem Solving Skills. Jurnal Penelitian Pendidikan IPA (JPPIPA), 6(2), 162-165. doi: https://doi.org/10.29303/jppipa.v6i2.427

\section{Introduction}

The rapid growth and acceleration of human activities on industrializations cause negative environment changes and worsen the quality of the environment. Thus, it needs a hard work to overcome that problem. One of the courses at the university that could potentially contribute to solve environment problems is Ecotoxicology.

Ecotoxicology is a study subject which plays important roles on the progress of education, besides, that study subject contributes on human life circle roles toward the environment. Thus, because ecotoxicology is able to accelerate critical, rational, and logical thoughts. Ecotoxicology is also a study subject that can provide skills to students to be able to use logical thought to solve several problem especially that appear on environment, and the materials contained in the study subject also can accelerate the skills of the students on analyzing environmental changes which will possibly happen in the future, so problem solutions can possibly be planned to overcome and 
solve negative effect of environment change that happen (Yulianto, 2017).

Others of the material subjects in ecotoxicology which can facilitate on overcoming and solving waste are bioremediation and Phytoremediation. Bioremediation is a technique about how to process waste by using microorganism to degrade chemical compound which is environmentally safe (Puspitasari, 2016).

Considering the importance of this study subject toward human circle life, it is expected that a teacher is able to design study source by applying relevant model on teaching learning process somehow that can facilitate problem solving skills, one of which is Problem Based Learning (PBL), it is a teaching learning process model that is designed based on authentic problems that direct students to do investigation aimed to accelerate problem solving skills (Arends, 2013).

Based on meaningful teaching learning theory Ausubel (1968) a contextual teaching learning process which correlate material subjects with daily life will be much more meaningful for the students, and will provide students with problem solving skills. According to a research by Argaw et al (2017), it is stated that teaching learning process based on problem can increase and accelerate problem solving skills and can also motivate students to study more active so the academic prestation can increase.

The aim of this study was to develop student worksheets based on problem based learning on bioremediation material subject to facilitate problem solving authentic skills in order to help students to find solution on environment problem.

\section{Method}

The type of the research is development research using ADDIE model. ADDIE model is a development research model consist of several steps, they are: analyze, implement, and evaluate (Branch, 2009).

\section{Research Designing}

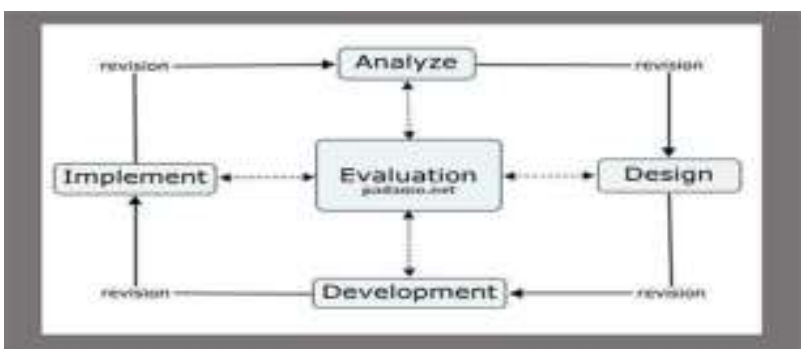

Figure 1. ADDIE model scheme (Branch, 2009)

Figure 1 it can be seen that ADDIE development model consists of five steps. The first step is analyzed. This steps consists of five steps, they are observing problems on the field of study, finding the goals of development, finding object of development, identifying components which is needed on development, and arrange plans for implementation and application of the development. The second step is design. This step consists of two activities, they are designing the whole component on product, and arranging the goal of product development. The third step is development. On this step, researcher develop research instrument, develop product based on the design, and do some revision. The fourth step is implemented, during this step researcher implement and apply the product by using one group pretest and posttest design. The last step is evaluated. This step is applied on each ADDIE step to achieve suggestion from lecturer and validator, somehow that it produces a research product that is valid and proper to be implemented as teaching learning tools.

The design applied during the implementation was one group pretest and posttest design, as shown:

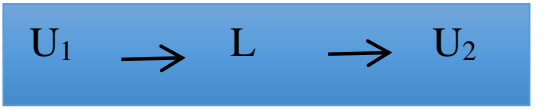

Figure 2. Scheme One Group Pretest-Postest Design (Leedy \& Ormrod, 2005)

Information:

$\mathrm{U}_{1}$ : Pretest, to know the problem solving skills of the students before application.

$\mathrm{L}$ : Application to the students using teaching learning materials based on problem based learning.

$\mathrm{U}_{2}$ : Posttest, to know the problem solving skills of the students after application.

\section{Research Subjects}

The population of the research object was the students of biology study program on the even semester who take ecotoxicology course. The research sample consists of 15 students which was conducted on March in Universitas Negeri Surabaya.

\section{Data Collections}

The technique of data collection on this research was validation technique. Validation technique was applied to achieve both qualitative and quantitative data. The quantitative data was in a form of score which is given by both validator (who are experts in both material subjects and teaching learning media) to developed student worksheets by using validation sheet to various aspect of student worksheet. Validation sheet uses scoring range between 1 to 4 with the category of $1,2,3$, and 4 were worse, less good, good, and excellent respectively. While the qualitative data is in a form of suggestion given by validator that can be used to revise the developed student worksheets. 


\section{Data Analysis}

Data analysis techniques were obtained from the average of the validation given by the two validators and then were used to determine the quality of the student worksheets in accordance with criteria determined by Ratumanan and Laurent (2011).

Table 1: Classification of Validation Criteria

\begin{tabular}{lll}
\hline Score Interval & $\begin{array}{l}\text { Rating } \\
\text { Category }\end{array}$ & Information \\
\hline $3,60 \leq$ score $\leq 4,00$ & Very valid & Very effective \\
$2,60 \leq$ score $\leq 3,59$ & Valid & Effective \\
$1,60 \leq$ score $\leq 2,59$ & less valid & Quite effective \\
$1,00 \leq$ score $\leq 1,59$ & invalid & Not effective \\
\hline
\end{tabular}

Percentage of agreement between score of two validators is based on the inter observer agreement obtained from analyzing the percentage of agreement (R) statistics as follows (Borich, 1994).

$$
\mathrm{R}=1-\frac{A-B}{A+B} \times 100 \%
$$

Where:

$\mathrm{R}$ : Reliability (An instrument is considered reliable if $\mathrm{R}$ $>75 \%)$

A: Validator score with a high score

B: Validator score with a low score.

\section{Result and Discussion}

Tabel 2 reveals that the developed student worksheets in validation and reliability were 3.36 and $90 \%$ respectively with valid category. These results were supported by the criteria of Ratumanan and Laurent (2011).

The valid category is achieved by this developed student worksheet. Because during the development, all the components, which stimulate and accommodate student activities both physical and mental activeness, were as a special attention. In addition, the student worksheets were developed to facilitate them on conveying information to solve the authentic environmental problems by stating the ideas or suggestions due to these problems (Depdiknas, 2006).

The developed worksheets also get suggestions from validators which aimed in order the student worksheets to be implemented better. The suggestion was including to provide enough time allocation, to change the topics, the available explanation of the pictures, and the standardized appearance of graphically. Based on those suggestions, the student worksheets were revised and evaluate again before using.

The developed student worksheets also revered to teaching learning model based on $P B L$ which was combined with problem solving skills indicators on every steps of teaching learning process. It means that the developed student worksheets reflected the teaching learning process based on authentic environmental problems. The syntax of teaching learning process was directing the students to problem, prepare the students to follow teaching learning activities, to guide a personal or teamwork research, to develop and to present scientific products, including to analyze and to evaluate problem solving process (Arends, 2008).

Problem solving skills indicators consist of identifying problem, examine problem, applying plan, and evaluate also reanalyze (Mourtos, 2004). The topics applied on designing student worksheets also considers authentic problem which is well known by students, happen around student's home, and the problem is a new one. The matter is correlated with the goal aimed to reach on this research. All these activities can facilitate student skills on problem solving.

That results of this research is also supported by Bahri et al (2018), which stated that problem based teaching learning model synchronized with problem solving based student worksheets as teaching learning source. Thus, it is known that the teaching learning materials affect toward the increase of the problem solving skills of the students.

Table 2. Validation Outcome of Student Worksheets

\begin{tabular}{|c|c|c|c|c|c|c|}
\hline \multirow[t]{2}{*}{ No } & \multirow[t]{2}{*}{ Aspect } & \multicolumn{2}{|c|}{ Score of Validation } & \multirow[t]{2}{*}{ Average } & \multirow[t]{2}{*}{ Category } & \multirow[t]{2}{*}{$\mathbf{R}$} \\
\hline & & V1 & V2 & & & \\
\hline \multirow{2}{*}{1} & a. Worksheets match with lecture goal & 3 & 4 & 3,5 & Valid & $86 \%$ \\
\hline & $\begin{array}{l}\text { c. Material Subject of Worksheet is well designed } \\
\text { and proper }\end{array}$ & 3 & 4 & 3,5 & Valid & $86 \%$ \\
\hline \multirow[t]{3}{*}{2} & Language & & & & & \\
\hline & b. Use proper Indonesian language & 3 & 3 & 3 & Valid & $100 \%$ \\
\hline & c. Use proper and understandable word vocabulary & 3 & 3 & 3 & Valid & $100 \%$ \\
\hline
\end{tabular}




\begin{tabular}{|c|c|c|c|c|c|c|}
\hline \multirow{2}{*}{ No } & \multirow[t]{2}{*}{ Aspect } & \multicolumn{2}{|c|}{ Score of Validation } & \multirow{2}{*}{ Average } & \multirow{2}{*}{ Category } & \multirow[t]{2}{*}{$\mathbf{R}$} \\
\hline & & V1 & V2 & & & \\
\hline \multirow[t]{14}{*}{3} & Precentation & & & & & \\
\hline & a. Generate motivation/interest/eagerness & 4 & 3 & 3,5 & Valid & $86 \%$ \\
\hline & b. Understandable Worksheet activity procedure & 4 & 3 & 3,5 & Valid & $86 \%$ \\
\hline & $\begin{array}{l}\text { c. Show teaching learning process based on PBL } \\
\text { 1. Directing student to the problem }\end{array}$ & 4 & 3 & 3,5 & Valid & $86 \%$ \\
\hline & 2. Preparing student learning & & & & & \\
\hline & 3. Guiding independent and group research & & & & & \\
\hline & 4. Present and develop the result of the discussion & & & & & \\
\hline & $\begin{array}{l}\text { d. Show teaching learning process which facilitate } \\
\text { problem solving skills }\end{array}$ & 4 & 3 & 3,5 & Valid & $86 \%$ \\
\hline & 1. Define or explain problem clearly & & & & & \\
\hline & 2. Examine problem & & & & & \\
\hline & 3. Do plan & & & & & \\
\hline & 4. Evaluate and revise & & & & & \\
\hline & e. Train skill process to student & 4 & 3 & 3,5 & Valid & $86 \%$ \\
\hline & Average Score & & & 3,36 & & $90 \%$ \\
\hline
\end{tabular}

Information: Validity: V1= Validator 1; V2=Validator 2

\section{Conclusion}

The developed student worksheets was valid to be implemented in teaching learning process to facilitate student' problem solving authentic skills.

\section{References}

Arends, R.I. (2008). Learning to Teach: Belajar untuk Mengajar.Yogyakarta: Pustaka Pelajar.

Arends, R.I. (2013). Learning to Teach Edisi 9. Jakarta: Salemba Humanika.

Argaw, A. S., Haile, B. B., Ayalew, B. T., \& Kuma, S. G. (2017). The Effect of Problem Based Learning (PBL) Instruction on Students' Motivation and Problem Solving Skills of Physics. Eurasia Journal of Mathematics, Science and Technology Education, 13(3),

857-871. https://doi.org/10.12973/eurasia.2017.00647a

Ausubel, D.P. (1968). Educational Psychology: a Cognitive View. New York: Holt, Rinehart and Winston.

Bahri, A., Putriana, D., Idris., \& Irma, S. (2018). The Role of PBL in Improving Biological ProblemSolving Skill. Jurnal Sains Mat, 7(2):114-124.

Borich, G.D. (1994). Observation Skills for Effective Teaching. Newyork: Merrill.

Branch, R.M. (2009). Instructional Design: The ADDIE Approach. New York: Springer.

Depdiknas. (2006). Kurikulum Tingkat Satuan Pendidikan. Jakarta: Depdiknas.

Leedy, P.D., \& Ormrod, J.F. (2005). Practical Research: Planning and Design. 8th $^{\text {th }}$ Edition. New Jersey: Pearson.

Mourtos, N. J., Okamoto, N. D., \& Rhee, J. (2004). "Defining, Teaching, and Assessing Problem Solving Skill". Artikel disajikan dalam UICEE

\section{Annual Coferenceon Engineering Education,} Mumbai.

Puspitasari, D. J. (2016). Study of Bioremediation in Polluted Soil of Pesticides. Kovalen, 2(3): 98-106

Ratumanan, T. G. \& Laurens, T. (2011). Penilaian Hasil Belajar pada Tingkat Satuan Pendidikan. Surabaya: Unesa University Press.

Sugiyono. (2016). Metode Penelitian Kuantitatif,Kualitatif dan RED. Bandung: PT Alfabet.

Valerie. (2018). Pemanfaatan Mikroba Yang Berpotensi Sebagai Agen Bioremediasi Limbah Pewarna Tekstil. FaST- Jurnal Sais dan Teknologi, 2(1). 32-47

Yulianto. (2017). Toksikologi Lingkungan. Pusat Pendidikan Sumber Daya Manusia Kesehatan. 